\title{
The environmental impact of human activities on the Mexican coast of the Gulf of Mexico: review of status and trends
}

\author{
J. A. Benitez ${ }^{1}$, R. M. Cerón-Bretón ${ }^{2}$, J. G. Cerón-Bretón ${ }^{2}$ \\ \& J. Rendón-Von-Osten ${ }^{1}$ \\ ${ }^{1}$ Instituto de Ecología, Pesquerías y Oceanografía del Golfo de México \\ EPOMEX, Universidad Autonoma de Campeche UAC, Mexico \\ ${ }^{2}$ Universidad Autonoma del Carmen UNACAR, Mexico
}

\begin{abstract}
The Mexican coastal zone of the Gulf of Mexico and Caribbean (CZGMC) is an important source of ecosystem services related to biodiversity, biological productivity, and nutrient balance. This region contains more than $50 \%$ of national wetlands, near $6,000 \mathrm{~km}^{2}$ of coastal lagoons, 24 estuaries, and the most extensive areas of coral reef in Mesoamerica. These habitats holds more than 8,500 species of marine invertebrates and fishes, 328 species of birds, 29 species of marine mammals, and share 5 out of the 11 species of current marine turtles. Its biological productivity ranges $100-2000 \mathrm{mg} \mathrm{C} \mathrm{m}^{2} \mathrm{~d}^{-1}$. Biodiversity and natural productivity in the CZGMC are connected to the integrity and health of coastal habitats. This paper analysed the main ecological features and the socioeconomic indicators for this region. Using GIS tools, census data, and geographic databases we compiled information from the last 30 years to assess anthropogenic impact sources, and determine trends on levels of pollution in coastal environments. Oil industry, tourism, fisheries, marine transportation, cattle ranching, and agriculture are the main economic activities on the CZGMC, which contribute more than $16 \%$ of the Mexican GDP. The current population on the six Mexican estates that border the Gulf is more than $1710^{6}$. One third of this population live within a narrow corridor of three $\mathrm{km}$ from the coastline. Within this area, human activities have cleared $65 \%$ of natural vegetation, causing the direct loss of habitats, which leads to a reduction of biodiversity. Also, the coastal population in this area produce near $110^{6} \mathrm{t} \mathrm{y}^{-1}$ of solid waste and about $1,50010^{6} \mathrm{~m}^{3}$ of wastewater, which have led to water quality deterioration.
\end{abstract}


The coastal zone of Tabasco, Campeche and the south portion of the state of Veracruz presented the highest concentration of atmospheric pollution, hydrocarbons, and heavy metals due to the oil industry activities, while the microbiological pollutions are associated with the main urban areas along the coast.

Keywords: Gulf of Mexico, Caribbean Sea, pollution, environmental impact trends, anthropogenic activity, heavy metals, atmospheric pollution.

\section{Introduction}

The Gulf of Mexico and Caribbean coastal margin has more than 3,200 km long, with a territorial sea and exclusive economic zone of over $829,540 \mathrm{~km}^{2}$. It extends along a wide latitudinal area containing a range of ecosystems from shallow waters of coral reefs, sea-grasses, to deep seabed and the continental slope (Bonilla et al. [1]). Over $50 \%$ of coastal wetlands of the country are located in this region, containing about $6,000 \mathrm{~km}^{2}$ of coastal lagoons, 24 estuaries and the largest areas of coral reefs. The size and diversity of these habitats produce a high biodiversity. In this region occur around 8500 species of marine fish and invertebrates; 228 bird species, of which $51(22.3 \%)$ are marine, $114(50 \%)$ aquatic and $63(27.7 \%)$ terrestrial. The Gulf is known for sharing the habitat of 5 of the 11 species of marine turtles that exist today; it has 29 species of marine mammals, 28 cetaceans (whales and dolphins) and a sirenia (manatee). Oceanographic conditions in the Gulf produce large biological productivity

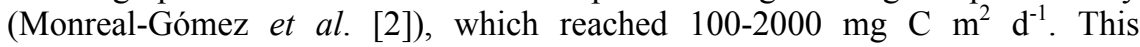
biological productivity supports important fisheries, which represent $40 \%$ of the national fish production

Biodiversity and natural productivity in the CZGMC are connected to the integrity and health of coastal habitats. Unfortunately, pollution and environmental impact problems are increasing by human activities, either because they eliminate natural areas, or because the generation of undesirable waste, or when ecological processes are altered. The magnitude of these problems is a function of the type and volume of these pollutants, as well as the type and extent of human infrastructure. The current paper analyses demographic, economic, and land use change trends of the last three decades to assess the volumes of waste, and to distinguish the highest impact activities.

\section{Methods}

A geographic database was integrated for the six states bordering the Gulf of Mexico (Fig. 1). This database included information from the population census, economic census, environmental statistics, and land use maps of the National Institute of Geography and Statistics (INEGI [3]), for the years 1990, 2000, 2010. This environmental geo-database (EG) was standardized and managed in a geographic information system. The impacts of human activities were primarily evaluated at state and county level. Also, a buffer area of $3 \mathrm{~km}$ was created along 


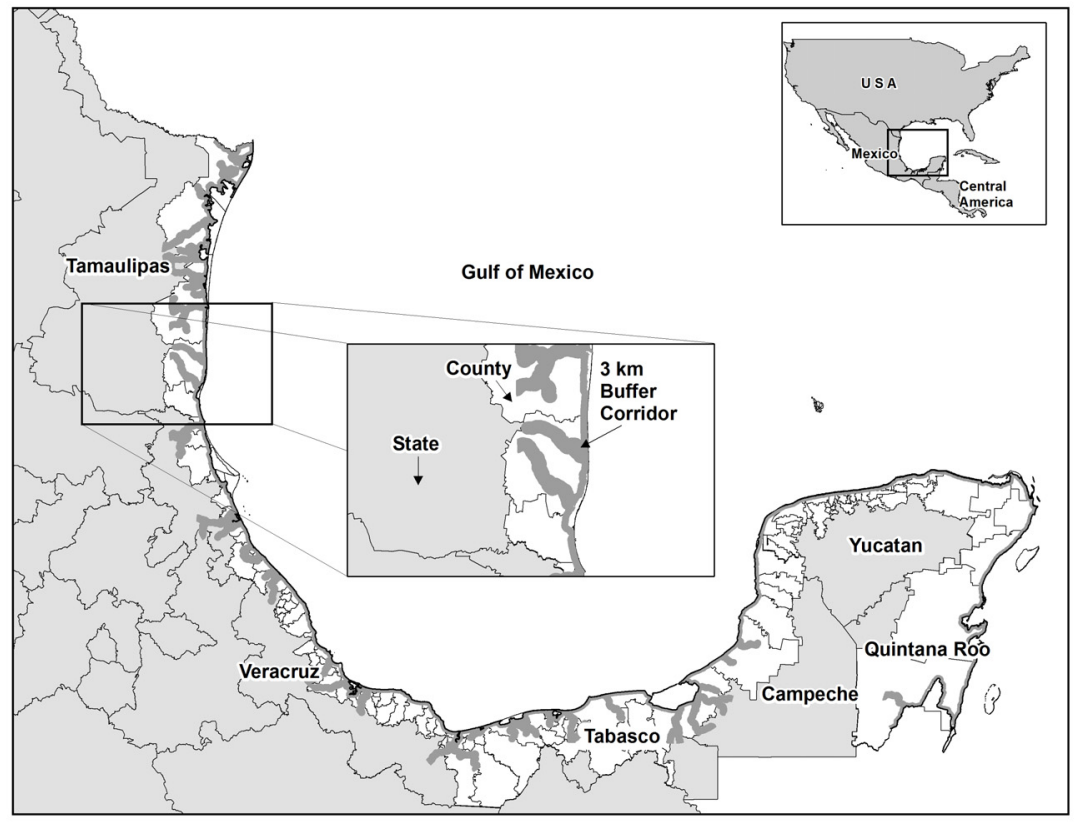

Figure 1: $\quad$ States and municipalities bordering the Gulf of Mexico. A buffer area of $3 \mathrm{~km}$ was created following the coastline and the last $20 \mathrm{~km}$ of main rivers.

the coastline and main rivers (last $20 \mathrm{~km}$ before reaching the ocean) to assess the human activities that are causing an immediate impact on the coastal zone.

At each level (state, county and $3 \mathrm{~km}$ buffer zone), the volumes of solid waste and sewage were calculated multiplying population by per capita indicators, and incorporates to the EG. Atmospheric pollution sources were estimated from literature review. In addition, data of pollutants levels was integrated to the EG, including atmospheric deposition fluxes, and the concentration of hydrocarbons (HCs) and heavy metals. Spatial analysis was used to assess the trends of human activities and the impact on environmental quality.

\section{Results and discussion}

\subsection{Demographic and socioeconomic trends}

According to the EG, states bordering the Gulf of Mexico currently contain over $1710^{6}$ inhabitants (Fig. 2), which represent approximately $15 \%$ of the national total. About half of this population $\left(9.510^{6}\right)$ live in the 108 coastal municipalities, and about one-third $\left(5.510^{6}\right)$ live within the first $3 \mathrm{~km}$ of the coast, which clearly show the intensive use that has been given to the coastal zone. More than $30 \%$ of the state population is concentrated in 10 cities of over 150,000 inhabitants. 


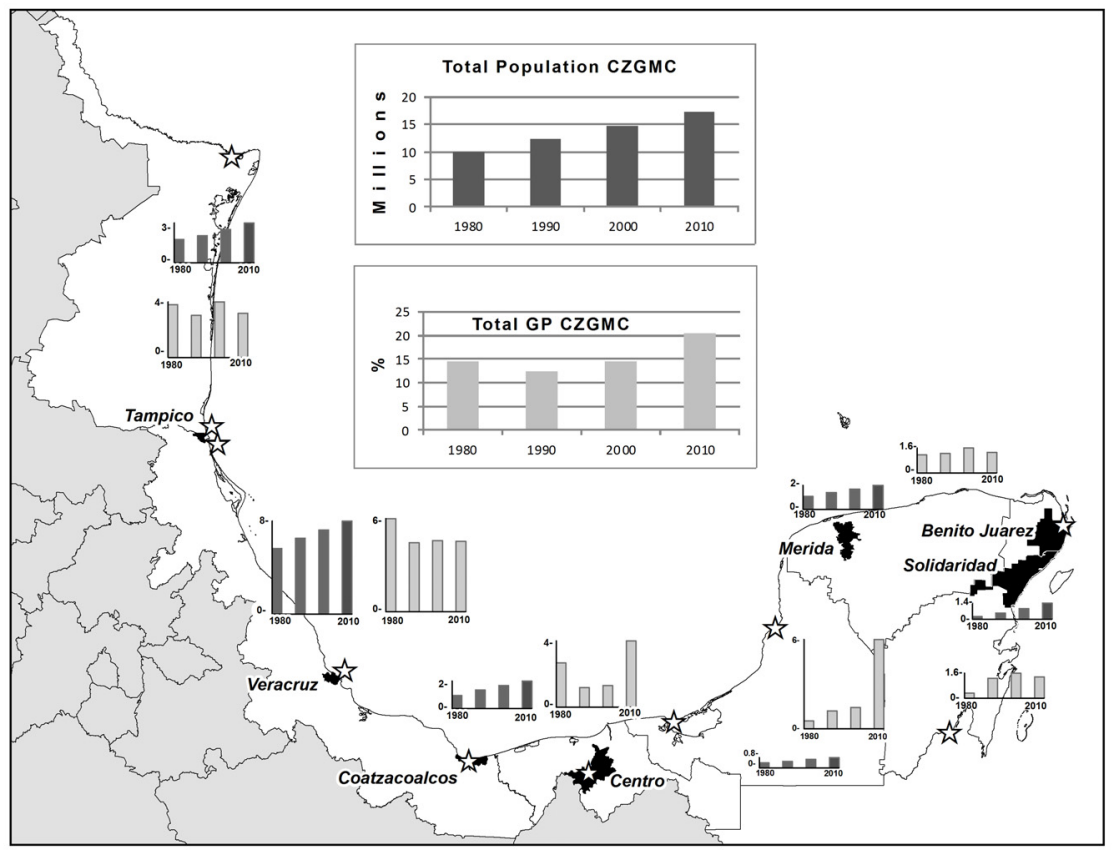

Figure 2: $\quad$ Trends of Population and Gross Product (\% contribution to NGP) in the states bordering the Gulf of Mexico. Black polygons are counties with high population or high GP. Stars indicate cities with more than 150,000 inhabitants.

Spatial and temporal analysis from the EG show that coastal municipalities have gradually reduced its growth rate to levels similar to the national average $(1.8 \%)$. However, some municipalities currently presented high growth rates, such as Altamira, Tamaulipas (4.48\%) and the municipalities of Tulum $(6.0 \%)$, Benito Juarez (6.9\%), and Solidaridad (8.1\%) in the State of Quintana Roo.

Data from the EG show that oil industry, tourism, marine transportation, cattle ranching, and agriculture are the main economic activities on the CZGMC, which contribute more than $16 \%$ of the Mexican GDP (Fig. 2). The region produces $2.510^{6} \mathrm{~d}^{-1}$ barrels of oil (98\% of national production), and contains $75 \%$ of installed capacity for oil refining. In terms of taxes, the Gulf oil industry contributes $38 \%$ of the funding for the public sector. The CZGMC accounts for $50 \%$ of the tourism market in the country (mainly in the coastal area of Quintana Roo), about $60 \%$ of national cargo container (mainly in the ports of Tamaulipas, and Veracruz), and nearly half of livestock production. Also, in this region an average of $235,000 \mathrm{t} \mathrm{y}^{-1}$ of fish are caught. Among this production it highlights the shrimp fisheries (30\% of national production), grouper exploitation in the Campeche Sound (16 $\left.000 \mathrm{t} \mathrm{y}^{-1}\right)$, shark and bivalve molluscs $(3.5 \%$ and $3 \%$ of national production, respectively). 
Data from the EG show that at the state level, Tamaulipas is important for international port activities (over $40 \%$ of national imports and exports), oil production, and agriculture, contributing in the past three decades with about $3 \%$ of national GDP. Meanwhile the State of Veracruz has reduced its contribution to national GDP from $6.1 \%$ in 1980 to $4 \%$ in 2010 . However, Veracruz State continues to occupy first place at national level in basic petrochemicals, electricity production and livestock, as well as being responsible for producing $40 \%$ of sugarcane, and operates nearly $20 \%$ of the national cargo container. In the case of Tabasco and Campeche, its contribution to GDP has increased substantially due to the oil industry, going from $2.9 \%$ and $0.5 \%$ in 1980 to $4.4 \%$ and $5.9 \%$ in 2010, respectively. The state of Quintana Roo has increased its share to GDP from the tourism industry, from $0.3 \%$ in 1980 to $1.4 \%$ in 2010 (Fig. 3).

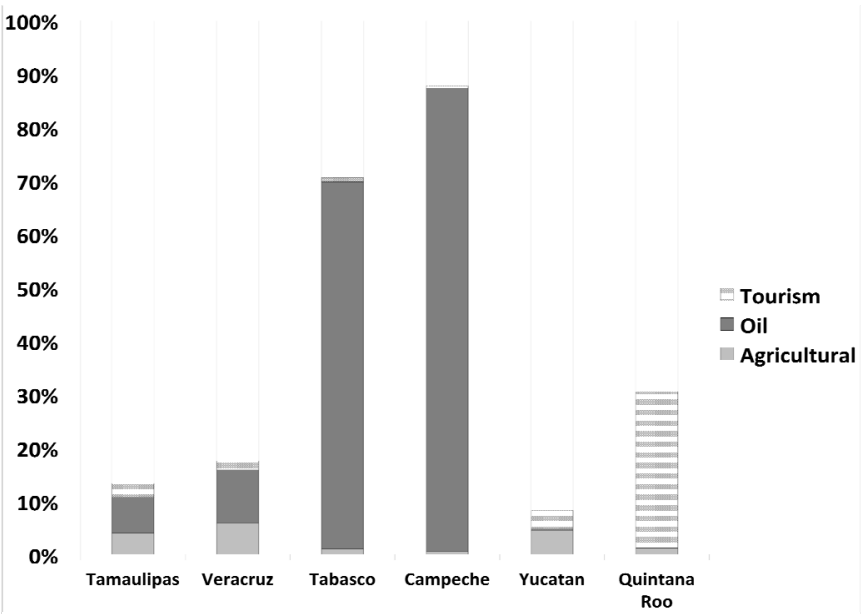

Figure 3: Contribution of human activities to the State Gross Product.

According to the EG, economic progress in most of the municipalities in the CZGMC has kept pace with population growth. However, the contribution of some municipalities to the national GDP was due to specific development of oil and tourism industries. Such is the case of the municipalities of Minatitlan in the State of Veracruz and Solidaridad, in the State of Quintana Roo.

Both at state and municipal levels, deforestation rates have been considerably lower than those reported from the 70s and 80s. This decrease is due to the most suitable areas for agriculture and livestock were already used before the $90 \mathrm{~s}$. Within the immediate coastal zone 16 municipalities stand out because they have lost more than $60 \%$ of natural vegetation within the $3 \mathrm{~km}$ corridor (shaded polygons in figure 4). 


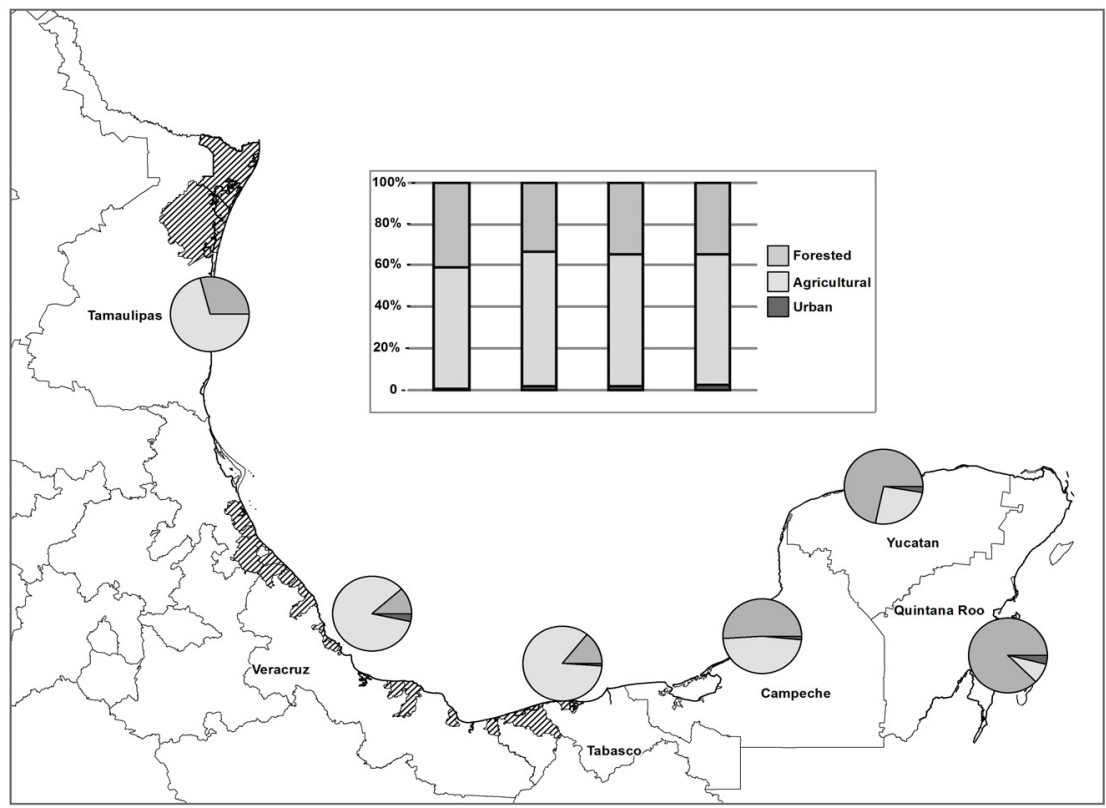

Figure 4: Land use changes in the states bordering the Gulf of Mexico. Shaded polygons represent coastal counties with less than $40 \%$ of natural vegetation within the $3 \mathrm{~km}$ coastal corridor.

\subsection{Environmental consequences}

Population growth and concentration in urban areas has generated large amount of wastes, while agricultural activities have eliminated natural areas. Added to this, economic growth linked to the oil and energy industries have resulted in the production of large volumes of pollutants. Environmental consequences of changes include loss of natural habitats, the generation of solid waste and wastewater, and emissions of pollutants to the atmosphere.

\subsubsection{Habitats loss}

Human activities have had a major impact on the loss of habitats in the CZGMC by eliminating two-thirds of the natural vegetation. It is very likely that the extinction of vegetation directly leads to the extinction of insects that depend on it and this in turn has a direct effect on the parasites and predators of these insects causing a domino effect on biodiversity [4]. In addition to this reduction, the removal of natural vegetation has resulted in increased habitat fragmentation with negative effects on biodiversity; see reviews by Fahrig [5], and Watson [6].

\subsubsection{Solid waste and wastewater}

Per capita generation of solid waste in the Gulf of Mexico is within the average country's generation $\left(0.95 \mathrm{~kg} \mathrm{~d}^{-1}\right)$; estimated $0.4 \mathrm{~kg} \mathrm{~d}^{-1}$ for rural areas 
and $1.5 \mathrm{~kg} \mathrm{~d}^{-1}$ in metropolitan areas. Considering the number of inhabitants these states produce about $310^{6} \mathrm{t}$ year $^{-1}$ of solid wastes, while coastal municipalities produces $1.610^{6} \mathrm{t} \mathrm{y}^{-1}$, with the Counties of Merida (Yucatan), Benito Juarez (Quintana Roo), Centro (Tabasco), Veracruz (Veracruz), and Tampico (Tamaulipas), which generates more waste (Fig. 5). In municipalities such as Solidaridad, Benito Juarez and Cozumel in the state of Quintana Roo, influx of floating population during the high season of tourism represent an increase in waste generation up to triple the regular amount.

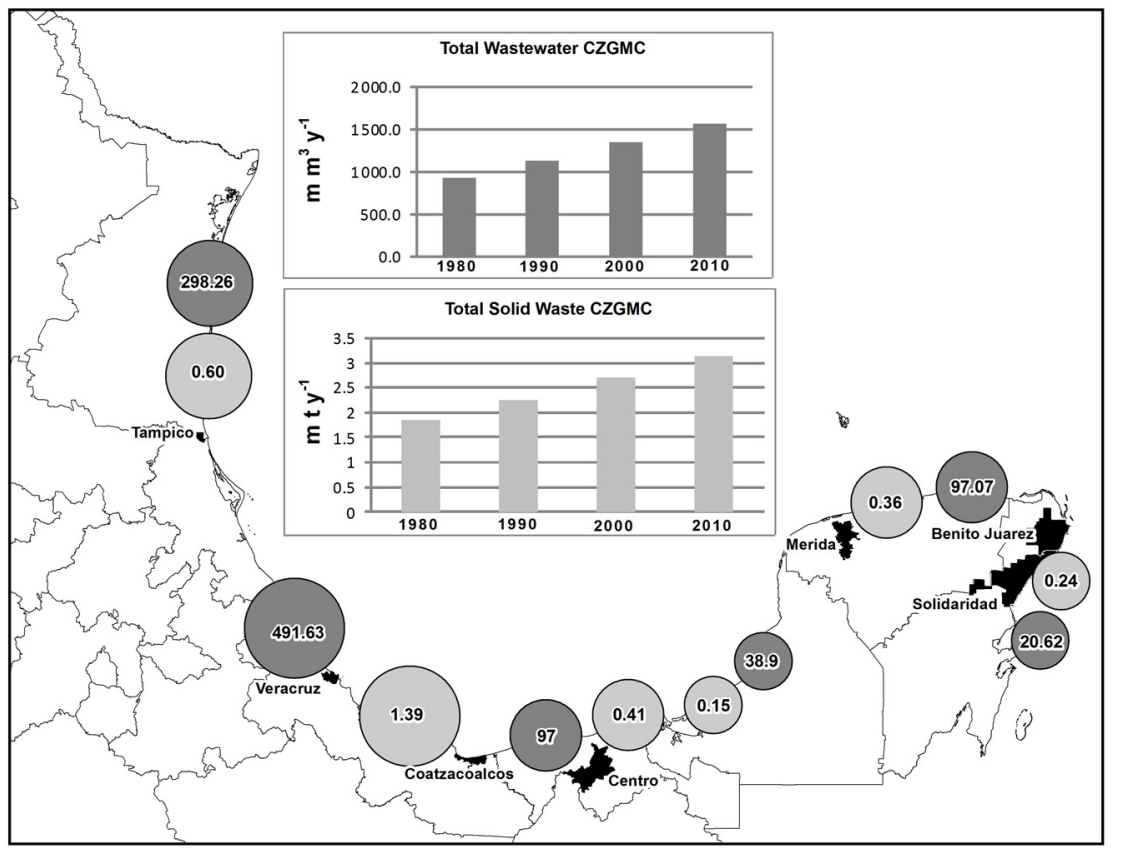

Figure 5: Solid waste $\left(10^{6} \mathrm{t} \mathrm{year}^{-1}\right)$ and wastewater $\left(10^{6} \mathrm{~m}^{3} \mathrm{y}^{-1}\right)$ produced at state level. Black polygons indicate the counties that produce more waste.

While all municipalities have collection services and waste disposal, data from the EG show that less than $10 \%$ treats these wastes. Added to this, the collection and disposal of waste that takes each municipality is not fully efficient and at least $2 \%$ of the residues are deposited in rivers. In view of these figures, and considering that $24,400 \mathrm{t} \mathrm{year}^{-1}$ of waste is produced within the $3 \mathrm{~km}$ coastal corridor, about 10,600 t year ${ }^{-1}$ of organic matter, 2,700 $\mathrm{t} \mathrm{year}^{-1}$ of plastic, and near $1,000 \mathrm{t} \mathrm{year}^{-1}$ of metals goes directly to the coastal zone.

Similar to the generation of solid waste, wastewater production is a serious problem. According to the EG the installed capacity of water treatment plants in the States of Tamaulipas, Veracruz and Tabasco is $30-50 \%$, and they not operated regularly. In some states such as Campeche and Yucatan, which have 
high vulnerable aquifers due to the karstic nature of the soil, less than $10 \%$ of wastewater is treated. In Quintana Roo, not all users are connected to the drainage system and some municipalities are struggle maintaining the network. Taking into account all these limitations in wastewater management, about $240,00010^{6} \mathrm{~m}^{3} \mathrm{y}^{-1}$ of wastewater are discharged into the CZGMC coming from the population living within the $3 \mathrm{~km}$ coastal corridor.

As a result of water discharges top 10 beaches of the State of Veracruz exceed levels of Enterococcus faecalis bacteria, becoming the most polluted state. Next in order of importance are the States of Tabasco and Campeche with a high concentration of faecal bacteria. According to the EG the volume of wastewater from urban areas has grown in proportion to population growth and urbanization. Meanwhile, discharges of industrial wastewater have had an increase of $10 \%$ in the last decade, according to the economic growth of the municipalities. Considering the organic matter discharged, industries that have the largest volumes are sugar $(31 \%)$, oil $(22 \%)$ and agriculture $(15 \%)$. Data from the EG are according to the levels of microbial pollution reported by several studies; See the review of Wong and Barrera [7] and references within.

\subsubsection{Atmospheric pollution}

Atmospheric pollutants can deteriorate historical buildings and archaeological zones, may cause damages to the human health and harmful effects on sensitive species. Schifter et al. [8] carried out an inventory of pollutants emitted from stationary and mobile sources related to oil and gas production and exploration industry facilities in the Bay of Campeche during 2000. Flares were identified as the major suppliers of pollutants, with almost $85 \%$ of the total emissions by activity. In addition, Villaseñor et al. [9] performed an air quality emissions inventory for offshore operations in the Bay of Campeche, and the shoreline of Tabasco. Oil and gas industry facilities located at the northwest region were responsible for the most of sulphur oxides and hydrocarbons emitted in this area. Dos Bocas Terminal and sour gas recompression station of Atasta were the main contributors to nitrogen oxides emissions with $52 \%$ of the total emissions.

Mejía and Rodríguez [10] characterized and estimated emissions of air pollutants from fuel burning on the Mexican border with USA in cities located into the Gulf Coastal zone. They found that gasoline burning in mobile sources is a larger contributor of $\mathrm{CO}$ emissions in the region (92\%), whereas diesel burning represented only $20 \%$ of $\mathrm{SO}_{2}$ emissions from a power plant located in Río Bravo. On the other hand, Mendoza et al. [11] estimated emissions of trace gases and particulate matter from forest and agricultural fires in north-eastern Mexico, identifying 2479 wildfires in the domain during the year 2000, which represented $\approx 3,300 \mathrm{~km}^{2}$ burned and 621,130 short tons emitted ( $81 \%$ being $\mathrm{CO}$ ). Deciduous forest, cropland and grasslands were identified as the vegetation kind more commonly burned in Tamaulipas State, which constitutes the main source of CO, Non-Methane Hydrocarbons, and particulate matter contributing to the degradation of air quality in this region.

Acid precipitation has been directly related to industrial emissions local and long-range transported. Specifically in the states of Gulf of Mexico, Bravo et al. 
[12] and Cerón et al. [13] measured chemical characteristics of precipitation in a site located in Quintana Roo. Both works concluded that $\mathrm{H}_{2} \mathrm{SO}_{4}$ was the main responsible of the observed acidity. In addition, Cerón et al. [13] reported that forest fires could be the main nitrate source during the dry season. This is strongly supported by the fact that forest fires emit nitrogen oxides that are rapidly converted to $\mathrm{HNO}_{3}$. In Veracruz, Bravo et al. [14] and Kahl et al. [15] carried out research work on rainwater chemistry. They identified the following potential regional sources for air parcels arriving to archaeological site El Tajín: oil platforms located in Bay of Campeche at $500 \mathrm{~km}$ East from El Tajín; a large electric power plant located in Tuxpan at $30 \mathrm{~km}$ North from this site; and the industrial cities of Tampico, Altamira, Matamoros, Monterrey and Brownsville, Texas. Báez et al. [16] reported that the enrichment of $\mathrm{SO}_{4}{ }^{2-}, \mathrm{NH}_{4}{ }^{+}$and $\mathrm{NO}_{3}{ }^{-}$ observed in the rainwater collected in Xalapa, Veracruz during the rainy seasons for the period 1993-1995 was due to the transport of upwind medium and longdistance emissions from the south-eastern Veracruz's oil refineries, petrochemical complexes and industrial zones by wind. On the other hand, during the dry season, the predominant wind direction in this site was from N$\mathrm{NW}$, passing over the oil refineries and petrochemical complexes of Tampico, Madero, Poza Rica and S-SE Texas.

In the southern coastal zone of Campeche, Cerón et al. [17] found that trace elements in rainwater exceeded background levels reported for sulphate and nitrate in coastal and marine remote sites. Also, they find significant fractions of $\mathrm{Cu}, \mathrm{Pb}, \mathrm{Zn}$ and $\mathrm{Ni}$ in dissolved form, showing a significant enrichment with a probable origin in anthropogenic sources. From the air-mass back trajectories analysis, they conclude that the main source for nitrate and sulphate was the sour gas recompression plant located in Atasta at $10 \mathrm{~km} \mathrm{NE}$ from their study site. In the other hand, at the north coastal zone of Campeche, Cerón et al. [18] demonstrated that nitrate and ammonium were the most abundant ions in the atmosphere, being attributed to biomass burning activities, forest fires and emissions from a local power plant.

Carbonyl compounds are of great interest because of their interactions in the smog cycles, their potential toxicity, their ability to photolyze, to produce free radicals and stable atmospheric products. Measurements of carbonyl levels in Montepío and Los Tuxtlas, Veracruz (Cerón et al. [19, 20]) were higher when the air masses came from SE, where oil refineries and industrial complexes in Veracruz and Tabasco are located.

\subsubsection{Coastal chemical pollution}

In the past 30 years, several scientific contributions have focused on the concentration levels of pollutants in the CZGMC. Among these are the books published by the Institute EPOMEX of the University of Campeche that have reviewed the status of pollution and environmental impact in the Gulf of Mexico and the Caribbean (see Botello et al. [21-23]). The analysis of all contaminants in the CZGMC goes beyond the scope of this study. For this reason, the present paper synthesizes the pollution of hydrocarbons ( $\mathrm{HCs})$, and heavy metals $(\mathrm{Pb}$, $\mathrm{Cd}, \mathrm{Cr}$ and $\mathrm{Hg}$ ) as indicators of pollution generated by human activities. These 
pollutants were selected due to their high toxicity, and because they are associated with municipal discharges and industrial processes.

Most metals selected as indicators of pollution have been reported consistently in the past 30 years (Fig. 6). However, the values of mercury in sediments appear only reported in the early 70 s to mid $80 \mathrm{~s}$. After that date there have been no reports of significant levels of mercury in sediments. Nevertheless, recent studies have reported $\mathrm{Hg}$ in fish from Coatzacoalcos area (IPEN [24]). These levels of HG are higher than the reference doses establish by US EPA $\left(0.22 \mathrm{mg} \cdot \mathrm{kg}^{-1}\right)$ for human consumption.

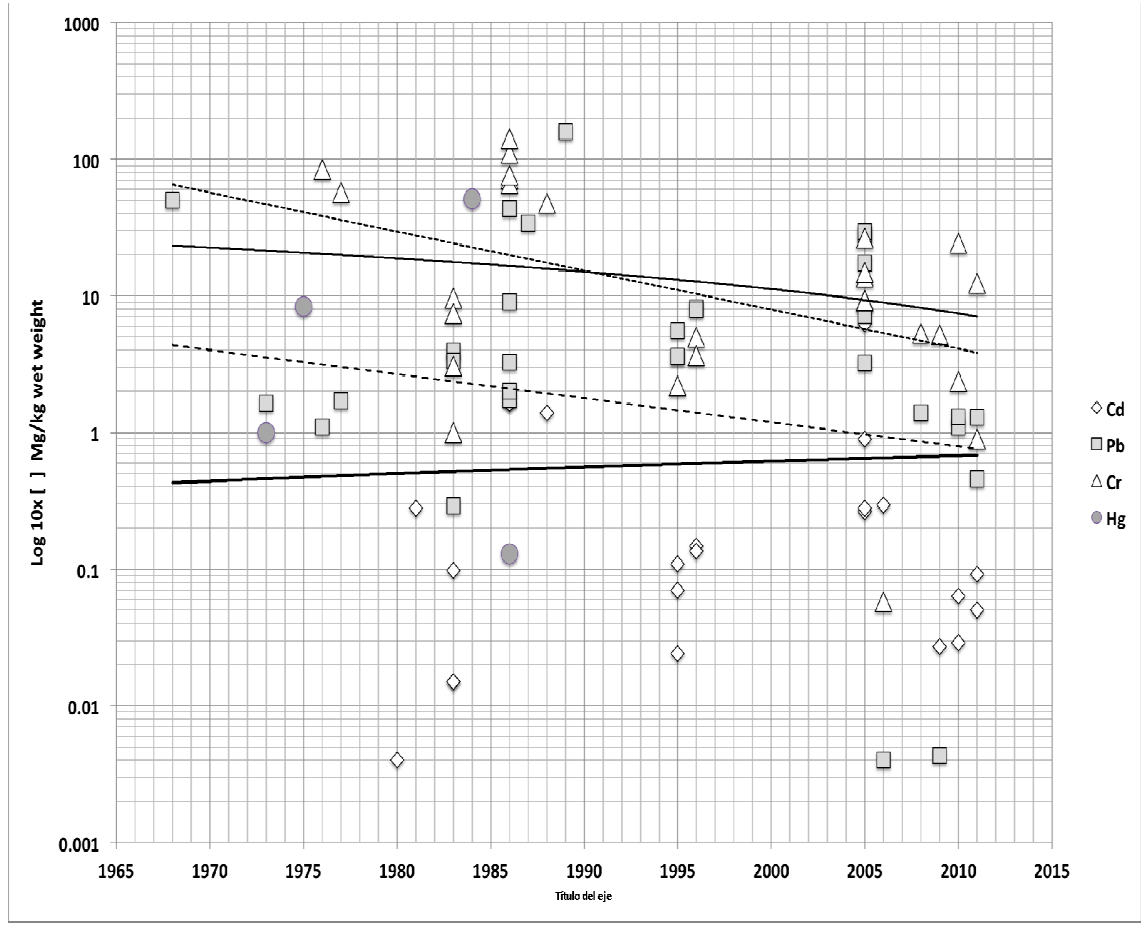

Figure 6: Temporal trend of heavy metal pollution coastal environment in the CZGMC. Original data from Botello et al. [21-23], and Benitez et al. [26].

Although $\mathrm{Pb}$ and $\mathrm{Cr}$ have been regularly reported in the last three decades their sediment concentration values have declined gradually. On the other hand the values of $\mathrm{Cd}$ have had a steady rise in their concentration values, which may indicate greater use. According to Figure 7, the highest concentrations of metals have been found in southern Gulf of Mexico, associated with oil and industrial areas of Coatzacoalcos (southern state of Veracruz), Dos Bocas (Tabasco) and Ciudad del Carmen (south Campeche state). Some high values of pollutants also have a connection with the activities of the Port of Veracruz (Veracruz) and Altamira (Tamaulipas). 


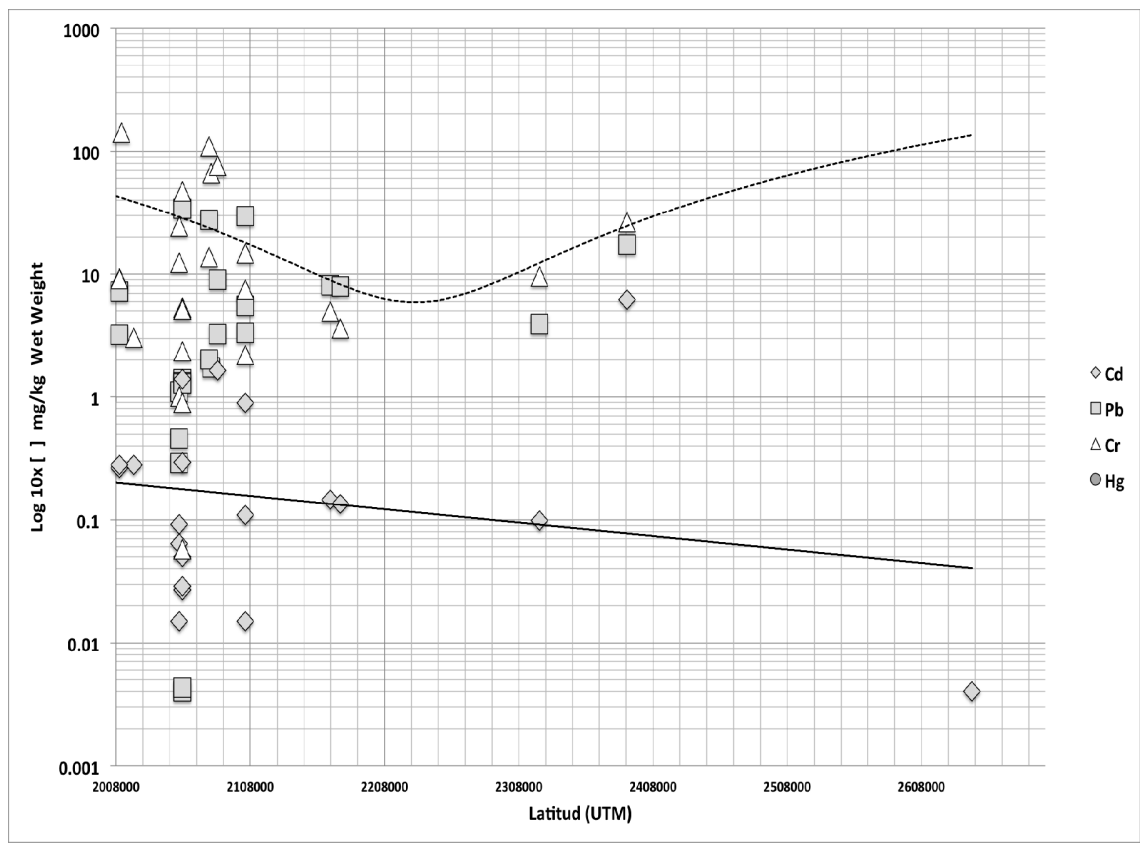

Figure 7: Spatial trend of heavy metal pollution coastal environment in the CZGMC. Original data from Botello et al. [21-23], and Benitez et al. [26].

With respect to the concentrations of HCs in CZGMC some studies indicate that the concentrations of these contaminants are higher in the southern portion of the Gulf, near large industrial complexes. According to Ponce and Botello [25] there have been high concentrations in water in the Tonala River $\left(1,189 \mu \mathrm{L}^{-1}\right)$, Rio Coatzacoalcos $\left(680 \mu \mathrm{L}^{-1}\right)$ and Laguna Mecoacan in Tabasco State $\left(112 \mu \mathrm{L}^{-1}\right)$, and lowest in the Laguna de Alvarado, Veracruz $\left(18 \mu \mathrm{L}^{-1}\right)$ and Laguna Bojorquez, Quintana Roo $\left(12 \mu \mathrm{L}^{-1}\right)$. On the other hand, the sediments that showed the highest concentrations of polycyclic aromatic hydrocarbons (PAHs) were Nichupté Lagoon in Quintana Roo State $\left(54 \mu \mathrm{g} \mathrm{g} \mathrm{g}^{-1}\right)$ and Sontecomapan Lagoon in Veracruz State $\left(11.7 \mu \mathrm{g} \mathrm{g}^{-1}\right)$. The lowest concentrations of PAHs were founded in the lagoons of Mecoacan in Tabasco State, and Tampamachoco and Pueblo Viejo in Veracruz State (3-5 $\left.\mu \mathrm{g} \mathrm{g}^{-1}\right)$. The predominant PAHs at these sites were of high molecular weight $(>5$ aromatic rings), which could indicate a pyrogenic origin. That is, these pollutants come from forest fires and slash-burn agriculture.

\section{Conclusions}

Population and economic growth have been the most important in increasing pollutant loading to the Gulf of Mexico factors. These factors continue to grow above the national average in some municipalities of the CZGMC. 
There is strong evidence that human activities have leads to a reduction of natural habitats, and significantly affect water quality deterioration. Within a narrow corridor of $3 \mathrm{~km}$ bordering the coastline, human activities have clearing $65 \%$ of natural vegetation, causing the direct loss of habitats. Also, coastal population in this area produce near $1 \mathrm{t} \mathrm{y}^{-1}$ of solid waste and $1,50010^{6} \mathrm{~m}^{3} \mathrm{y}^{-1}$ of wastewater.

The coastal zone of Tabasco, Campeche and the south portion of the state of Veracruz presented the highest concentration of atmospheric pollution, HCs, and heavy metals due to the oil industry activities. In the case of PAHs the main origin of these compounds are wildfires, while the microbiological pollutions are associated with the main urban areas along the coast.

\section{References}

[1] Bonilla, H., Walrher, M. \& Ramírez, G., Biodiversidad marina y turismo ecológico en áreas naturales protegidas de México (Chapter VIII), Medio ambiente y política turística en México. Ivanova, A. \& Ibáñez, R. (Coord), SEMARNAT: pp. 135-148, 2012.

[2] Monreal-Gómez, M., Salas, D. \& Gracia, A., Golfo de México, circulación y productividad. Ciencias 76, pp. 25-33, 2004.

[3] Instituto Nacional de Estadística, Geografía e Informática. Bases de datos digitales de los censos económicos y de población de 1980, 1990, 2000 and 2010; base de datos cartográfica de uso del suelo y vegetación, Series I, II, III and IV; Anuarios estadísticos nacionales.

[4] Stuart, F., Sala, O.E. \& Huber-Sannwald E. (Eds) Global Biodiversity in a Changing Environment. Scenarios for the $21^{\text {st }}$ Century. Ecological Studies 152. Springer-Verlag, New York, 2001.

[5] Fahrig, L., Effects of Habitat Fragmentation on Biodiversity. Annual Review of Ecology, Evolution, and Systematics 34, pp. 487-515, 2003.

[6] Watson M.L., Habitat fragmentation and the effects of roads on wildlife and habitats. Conservation Services Division. New Mexico Department of Game and Fish, 2005.

[7] Wong, I. \& Barrera, G., Estado actual de la contaminación microbiológica en el Golfo de México. Golfo de México Contaminación e Impacto Ambiental: Diagnóstico y Tendencias, $2^{\text {nd }}$ Edicion. Eds. Botello, Rendónvon Osten, J., Gold-Bouchot G. \& Agraz-Hernández C. Univ. Autón. de Campeche, Univ. Autón. de México, Instituto Nacional de Ecología, pp. 487-504, 2005.

[8] Schifter, I; González, C., Miranda, A. \& López, E., Air emissions assessment from offshore oil activities in Sonda de Campeche, Mexico. Environmental Monitoring and Assessment, 109, pp. 135-145, 2005.

[9] Villaseñor, R., Magdaleno, M., Quintanar, A. Gallardo, J., López, M., Jurado, R., Miranda, A., Aguilar, M., Melgarejo, L., Palmerín, E., Vallejo, C. \& Barchet, W., An air quality emission inventory of offshore operations for the exploration and production of petroleum by the Mexican oil industry. Atmospheric Environment, 37, pp. 3713-3729, 2003. 
[10] Mejía, G.M \& Rodríguez, M., Characteristics and estimated air pollutant emissions from fuel burning by the industry and vehicles in the Matamoros-Reynosa border region. Environment International 23(5), pp. 733-744, 1997.

[11] Mendoza, A., García, M.R., Vela, P., Lozano, D.F. \& Allen, D., Trace gases and particulate matter emissions from wildfires and agricultural burning in northeastern Mexico during the 2000 fire season. J. of Air and Waste Management Association 55, pp. 1797-1808, 2005.

[12] Bravo, H.A., Saavedra, M.I.R., Sánchez, P.A., Torres, R.J. \& Granada, L.M.M., Chemical composition of precipitation in a Mexican Maya region. Atmospheric Environment 34, pp. 1197-1204, 2000.

[13] Cerón, R.M.B, Padilla, H.G., Belmont, R.D., Torres, M.C.B., García, R.M. \& Baéz, A.P., Rainwater chemical composition at the end of the midsummer drought in the Caribbean shore of the Yucatan Peninsula. Atmospheric Environment 36, pp. 2367-2374, 2002.

[14] Bravo, A., Soto, R., Sosa, R., Sánchez, P., Alarcon, A., Kahl, J., \& Ruíz, J., Effect of acid rain on building material of the El tajín archaeological zone in Veracruz, Mexico. Environmental Pollution 144, pp. 655-660, 2006.

[15] Kahl, J., Bravo, H., Sosa, R., Sánchez, P., Alarcón, A. \& Soto, R., Characterization of atmospheric transport to the El Tajín archaeological zone in Veracruz, Mexico. Atmósfera 20, pp. 359-371, 2007.

[16] Báez, A., Padilla, H., Cervantes, J., Pereyra, D. \& Belmont, R., Rainwater chemistry at the eastern flanks of the Sierra Madre Oriental, Veracruz, Mexico. Journal of Geophysical Research 102, pp. 23, 329-23, 336, 1997.

[17] Cerón, R.M., Cerón, J.G., Carballo, C., Aguilar, C., Montalvo, R., Benítez, J.A., Villareal, Y. \& Gómez, M., Chemical Composition, fluxes and seasonal variation of acid deposition in Carmen Island, Campeche, Mexico. Journal of Environmental Protection, 4, pp. 50-56. 2013.

[18] Cerón, R.M., Cerón, J.G., Cárdenas, B., Ortínez, A., Carballo, C., Díaz, B. \& Muriel, M., Evaluation of dry atmospheric deposition in two sites in the vicinity of fuel oil-fired power plants in Mexico. Air Quality, Monitoring and modelling, ed. S. Kumar \& R. Kumar. Intech. Janeza Trdine 9, 51000 Rijeka, Croatia. pp. 167-184, 2012.

[19] Cerón, J.G., Padilla, H., Belmont, R., Cerón, R.M. \& Báez, A., Measurements of $\mathrm{C}_{1}-\mathrm{C}_{4}$ carbonyls in some forested regions in Mexico. Air Pollution XII, ed C.A. Brebbia. WIT Press. Ashurst Lodge, Ashurst, Southampton, SO40 7AA, United Kingdom. pp. 445-454, 2004.

[20] Cerón, J.G., Padilla, H., Belmont, R., Torres, M.C., Moya, M. \& Báez, A., Measurements of $\mathrm{C}_{1}-\mathrm{C}_{4}$ carbonyls at forested regions in Mexico. Atmósfera, 18, pp. 103-125, 2005.

[21] Botello A.V., Rojas-Galavíz J.L., Benítez J.A. \& Zárate-Lomelí D. (Eds) Golfo de México: Contaminación e impacto ambiental: diagnóstico y tendencias. EPOMEX Serie científica 5. Universidad Autónoma de Campeche. México. 666 p., 1995. 
[22] Botello A.V., Rendón-von Osten, J., Gold-Bouchot G. \& AgrazHernández C. (Eds). Golfo de México Contaminación e Impacto Ambiental: Diagnóstico y Tendencias, 2da Edicion. Univ. Autón. de Campeche, Univ. Autón. de México, Instituto Nacional de Ecología. 696 p., 2002.

[23] Botello A., Rendón-von Osten, J., Benítez J. A. \& Gold-Bouchot G. (Eds), Golfo de México Contaminación e Impacto Ambiental: Diagnóstico y Tendencias, $3^{\text {rd }}$ Edicion. Instituto EPOMEX/UAC, Instituto de Ciencias del Mar and Limnología-UNAM, CINVESTAV/IPN Unidad Mérida, Ecología Aplicada del Sureste AC., in press.

[24] IPEN, Industria química y petroquímica en la Cuenca del río Coatzacoalcos, México; la concentración de mercurio en los peces del río Coatzacoalcos en el context de las negociaciones del convenio internacional. Informe de Campaña IPEN por un mundo libre de mercurio. México, Praga, Estocolmo, April, 2013.

[25] Ponce Vélez, G., \& Botello, A. V., Niveles de hidrocarburos en el Golfo de México, Golfo de México. Contaminación e Impacto Ambiental: Diagnóstico y Tendencias, 2da Edición, ed. A. V. Botello, Rendón-von Osten, J., Gold-Bouchot G. \& Agraz-Hernández C. (Eds.). Univ. Autón. de Campeche, Univ. Nal. Autón. de México, Instituto Nacional de Ecología, p. 269-298, 2005.

[26] Benitez J.A., Vidal, J., Brichieri-Colombi T. \& Delgado-Estrella, A., Monitoring ecosystem health of the Terminos Lagoon region using heavy metals as environmental indicators. C.A. Brebbia and T-S. Chon, Environmental Impact. Wit Press, London, pp. 349-358, 2012. 